\title{
Effects of Chinese Level of Technology on the Economic Growth of Small Scale Fish Traders in Kisumu County, Kenya
}

\author{
Waga Gregory Kelly Otieno \\ MA Student: Department of Public Policy and Administration \\ Kenyatta University \\ Kenya \\ Dr. Jane Gakenia Njoroge \\ Lecturer: Department of Public Policy and Administration \\ Kenyatta University \\ Kenya
}

\begin{abstract}
Over the last decade, bilateral trade relations between Kenya and China have led to tremendous transformation of economic growth affecting the small scale traders including small scale fish traders. While the influx of Chinese goods has had a negative effect on the local industry, it has also led to an increase in Chinese level of technology related to fishing. Pragmatic researches conducted have revealed conceptual, contextual and topographical gaps. This research hence sought to assess the effects of Chinese level of technology on the economic growth of small scale fish traders in Kisumu County. The research was conducted in Kisumu County; based on 167 respondents (5 state departments for Trade Directorate heads, 8 beach managers and 154 fishers) in the selected beaches along Lake Victoria. The beaches and fishers were included in the sample using systematic random sampling technique and Nassiuma (2000) sampling formulae respectively. Trade directorate heads' were sampled using purposive sampling technique. Interview guides and questionnaires were used to obtain primary data. The experts were consulted to test content and predictive validity. Test-retest coefficient was used to test for instrument reliability and a reliability of 0.7 was accepted. The study applied dependency theory supported by Innovative Growth theory echoing the significance of innovative entrepreneurs on economic growth. Data obtained was analyzed with the help of SPSS and descriptive and inferential statistics were presented in figures and tables. Interpretation and discussion of the results was guided by the specific objectives of the research. The study revealed that Chinese level of technology had a positive and significant effect on economic growth of small scale fish traders in Kisumu County and concludes that improvement of Chinese level of technology improves economic growth of small scale fish traders in Kisumu County. The study recommends fishers to consider the full adoption of modern fish farming technology (fish caging and fish ranching) to improve fish volume hence ameliorate their fish business. In addition, accredited fishers should utilize modern equipment and tools (motor boats) from China in their fishing business as well as cooling and storage facilities to facilitate large scale fish storage and longer preservation hours to boost business.
\end{abstract}

Key Words: Economic Growth, Fish Traders, Technology

\section{Introduction}

\subsection{Introduction and Background}

Studies involving factors influencing economic growth have been controversial among theoretical and empirical growth scholars as there is little agreement on them up until now (Odhiambo \& Chirwa, 2016). The study further argues that 2 key discoveries have guided most on-going discourses on economic growth in the context of economic growth theory and they are neoclassical growth theory and endogenous growth theories. Studies on Bangladesh in the period (1970-2007) indicated that changes in trade relations and FDI are desirably and substantially linked to economic growth (Rao\& Hassan 2011). Chang and Mendy (2012) studying 36 African countries concluded that imports, exports and trade relations are desirably and substantially linked to economic growth.

Fish trade being a major economic activity along Lake Victoria, job opportunities for local residents have been actualized as well as revenue generation for the government through exports and foreign exchange meliorating food security (Kamau and Ngigi, 2013). Inland water from Lake Victoria and rivers; Nyando and Sondu-Miriu with a total of 19 gazetted Beach Management Units elevate Kisumu County (CIDP II, 2018). Fishing industry (Kenya) 
has employed approximately 50,000 fishers and also 800,000 individuals involved in fish processing and trade plus exports generating up to US\$ 60 million in export returns (GoK, 2010).

In 1995, over 560,000 people were employed in the fisheries industry of Kenya, capturing a quarter of the Country's total employment (Omwenga et al., 2004). The use of traditional technologies like boats and rafts, inadequate cooling storage equipment and an inappropriate processing plant has hindered the fish business and small scale fish traders (Onjala, 2008). However, the relationship between Kenya and China has been on the rise, since the year 1964, with notable opportunities in the areas of economy and technology (Kamau, 2007).

\subsection{Statement of the Problem}

A number of scholars have conducted studies on the effect of bilateral trade relations between China and Kenya with a keen interest in the transport sector, infrastructural development, imports and exports and how these relations affect the economic growth of Kenya. For instance, Wanjiku et al. (2018) notes that Chinese FDI has been critical in stirring up Kenya's economic growth, Kamau (2007) argues that relatively cheap textile imports from China and second hand cloth importation has led to a steady decline of the East African Regional market share of Kenya export of clothing. In addition, while the influx of Chinese goods has had a negative effect on the local industry as indicated by Siringi (2018), it has also led to an increase in Chinese level of technology related to fishing. This study thus sought to assess the effects of Chinese level of technology on the economic growth of small scale fish traders in Kisumu County.

\section{Literature Review}

\subsection{Economic Growth and Development}

Husain (2009) studying Pakistan argues that investment (public) influences economy in 2 ways; that is, government cuts down on their spending to support alternative expenditure when they favour public investment. Money supply in the economy is infringed when the Central bank fails to print more leading to diminished job opportunities and consequently aggregate demand depletes and according to Ames et. al. (2001) this eventually diminishes the output, demand aggregate goes down, and creates income and investment niche and consequently leading to depression. The second way is when government attempts to close the gaps, they heavily rely on foreign aid; which elevates GDP-debt position and depletes foreign exchange reserves when repaying such loans. Ivic (2015) opines that economic growth and development involves the transformation in raw material production within a limited period of time, normally a year. The studies further suggest that economic development entails rise in raw material production, socio-economic processes and transformation attributed to economic impact and other elements past such economic factors (Haller, 2012). Economic development hence is a long term process that takes time.

According to Rabnawaz and Jafar (2015), revenue facilitates the economy to utilize a portion of GDP on public expenditure leading to job opportunities hence income level shoots up. The labour market demand may act as a substantive way of adding to economic growth. Models for labour market significantly influence such matters (Fields, 2006) and according to Fields (2003) and American Development Bank (2003) wages are fixed in most Nations where trade unions are powerful, minimum wage is substantial or government follows own pay policies. Fields (2001); David and Kraay (2002) argue that poverty levels have been reduced by rampant economic growth and when poverty level goes up then economic growth declines.

Nyandat and Owiti (2013) however argues that despite the recent drop in performance of freshwater aquaculture production, Kenya has a great potential for fish farming with over 1.14 million hectares possibly available to facilitate a production limit above 11 million tonnes annually. KMFRI (2019) report suggests that Kenya imported 22,362 tonnes of fish from China an increase from 19,127 tonnes at the cost of sh. 1.5 billion in 2017. This has indicated a rise by $11.8 \%$ of imported fish from China hitting a record of sh. 1.7 billion in 2018. There has been an influx of Chinese fish into the Kenyan market causing diplomatic friction as well as economic implications.

\subsection{Chinese Level of Technology}

Urel and Harm (2009) and Njoroge (2020), conquer that a consistent increased level of resources spent on innovation of advanced technologies leads to a consistent increase in economic growth in China and Walsh (2003) opined that R\&D efforts may have brought about rewards and implications concerning U.S.-China relations influencing innovation and in the long run economic growth and development. In 2013, Chinas total fishery production hit 617 million tonnes a portion of a third of the global total fishery production attributed to over 200,000 marine vessels and 2,460 distant-water fishing vessels in 2014. The studies further suggest that China fully exploited and utilized her entire fishery resources making sure that the trade expanded and became logical and sustainable through sound sea farming and sea ranching. Logical fishing policies and joint efforts by fishers and scientists led to Chinese success Technologically, in 1957 only a handful of 52,225 ships were motorized with a total tonnage of 1.4 million (mostly small and old vessels); however by 2013, a total of 694,905 electrically 
powered ship entered into the fishing industry. The studies further indicate that by 1976, the technology advanced to 22,000 fishing powerboats, 8.9 times as many as in 1959. Capacity of fishing fleet hit 1.52 million.

Sea farming and ranching also developed upwardly and new government policies, reforms and free access to foreign technology strongly supported and enhanced the development of the fish industry (Hongzou, 2015).

In 1999 there existed a total of 210 fisheries research institutes in China which contributed in basic and applied research for aquaculture and technological development in the fisheries industry. Scientific advancement and technological innovations form the basis of immense aquaculture production in China (FAO, 2014). This study hence sought to answer the question, "Does Chinese level of technology affect economic growth of small scale fish traders?"

\section{Theoretical Framework}

The study applied 2 theories; Dependency theory supported by Innovative growth theory as it stresses on the significance of entrepreneur innovators as key elements of economic growth asdependency theory was concerned on the manner in which developing economies heavily relied on developed economies through FDI and loans hence promoting social inequalities and poverty.

\subsection{Innovative Growth Theory}

Under his study "Theory of Economic Development" Schumpeter proposed the term 'innovation' into the economic field and in a different way looked at the significance of the entrepreneur in terms of economic growth (Lavvor\&Kapoguzov, 2006). He emphasized the significance of innovative entrepreneurs as the main driving force toward economic growth; from stagnated equilibrium, based on entrepreneurial skills (Braunerhjelm, 2010) and according to Schumpeter an entrepreneur is someone with the will and ability to convert a new idea or invention into a successful innovation (Kumar, 2011).

Schumpeter supported balance of payment (per equilibrium); hence this was the essence of the study and in his argument the energy behind development involved the transformation in the economic realm. This was as a result of various factors that is; abrupt discovery of new sources of supply, however the key factor remained entrepreneurial innovation which triggered development. An entrepreneur is an individual who transforms uncertainty into a calculated risk and according to Hongzhou (2015), China's technological advancement in the 1950s brought about the installation of 78,000 diesel boat engines and marine capture fisheries produced 546,000 metric tonnes. The number of equipped boats however, increased by end of 1950 hence leading to an increase of marine capture fisheries to 1.754 million metric tonnes.

In this theory, the driving force of development lies squarely in the innovator, business person, creative individual and an entrepreneur. He thus, possesses the initiative, risk taking and visionary qualities. Schumpeter further argued that dominance was affirmative as it was made possible through implementation of new combinations of factors of production, innovatory changes in production technology, creation of new products, entry into new markets among others (Lavvor \& Leapoguzov, 2006). Schumpeter explained the nature of economic development as the 'execution of new combinations' as; introduction of new factors of production, introduction of new products, opening a new market, new organization of an industry and conquest of new supply of raw materials. He viewed these unique forms of economic transformation as development. The findings above were hence relevant to the study topic and helped bridge the study gap.

\section{Research Methodology}

This study employed descriptive survey design (quantitative and qualitative methods were used to extract useful data from respondents).According to Nassaji (2015), descriptive research/ survey aim at explaining an occurrence and its inherent characteristics. The study's target population was 881 accredited fishers, 8 beach managers and 5 heads of state department for trade directorates. This study hence, used a systematic random sampling technique to select the 8 beach landings (represented by 8 beach managers), applied Nassiuma (2000) formula to determine the number of fishers from 8 respective beaches ( 154 accredited) and used purposive sampling technique to select the 5 heads of state department for trade. This gave a total number of 167 respondents for the study.

Nassiuma's (2000) formula;

$\mathrm{n}=\mathrm{NC}^{2} \div \mathrm{C}^{2}+(\mathrm{N}-1) \mathrm{e}^{2}$

Where n-sample size

$$
\begin{aligned}
& \text { N-Population size } \\
& \text { C-Coefficient of variation } \leq 30 \% \\
& \text { e- Margin of error fixed between } 2-5 \%
\end{aligned}
$$


Table 1 shows how the sample size has been determined using Nassiuma (2000) formulae.

Table 1: Selected Beach Landings and Sampling Grid

\begin{tabular}{|c|c|c|c|c|}
\hline Beach Name $(n=8)$ & Beach Manager & Accredited Fishers & $\begin{array}{l}\text { Number of Fishers in the } \\
n=N C^{2} \div C^{2}+(N-1) e^{2}\end{array}$ & sample \\
\hline Kichinjio & 1 & 233 & $14.5625 \div 0.64=22$ & \\
\hline Paga & 1 & 173 & $10.8125 \div 0.4925=21$ & \\
\hline Obange & 1 & 126 & $7.875 \div 0.375=21$ & \\
\hline Nduru & 1 & 86 & $5.375 \div 0.275=19$ & \\
\hline Ngege & 1 & 83 & $5.1875 \div 0.2675=19$ & \\
\hline Ochok & 1 & 68 & $4.25 \div 0.23=18$ & \\
\hline Ogal & 1 & 60 & $3.75 \div 0.21=17$ & \\
\hline Nyandiwa & 1 & 52 & $3.25 \div 0.19=17$ & \\
\hline Total & 8 & 881 & 154 & \\
\hline
\end{tabular}

This study employed primary data, collected using interview guide(s) and questionnaire(s). The structured questions helped save data collection and analysis time and also cut down on cost spent in data collection. Additionally, the unstructured questions helped yield in-depth information from respondents. Key informant interview guide (s) were used on beach managers and heads of state department for trade (directorate) and yielded key information on fish trade and diplomatic relations between Kenya and China. The questions covered all the 3 study objectives.

The researcher conducted a pilot study in the state department of trade, Paga and Kichinjio beaches in Kisumu County. The pilot group was randomly sampled and included 10\% of the sample size. Wilson (2014) opines that $10 \%$ of the sample needed for a comprehensive study should be employed in a sample size. The researcher consulted the research supervisor on her expert opinion on content validity to ensure instrument's validity. After piloting, proof-reading was done to make certain that the face and content validity were achieved. Test re-test reliability coefficient was used to determine the level of internal consistency of the research instrument and a reliability of 0.7 was acceptable.

\subsection{Data Analysis Procedure and Presentation}

The questionnaire(s) yielded quantitative and qualitative data. Qualitative data from the open ended questions in the questionnaire(s) were organized thematically and later coded for conversion information quantitative form. The interview guide(s) consequently yielded qualitative data which was edited, restated and summarized for clarity and good understanding before being grouped thematically (according to the study objective(s)) to support quantitative data findings. The researcher entered the quantitative data into statistical software known as Statistical Package for Social Sciences (SPSS). In the quantitative analysis, the researcher employed descriptive statistics (mean, frequency, and percentages) to summarize the information gathered as well as inferential statistics presented in tables and figures. The findings were then presented in frequency tables and bar graphs and according to Kutner et al. (2004); a linear regression was employed to demonstrate the relationship between the dependent and independent variables. The study applied the regression model below:

$\mathrm{Y}=\beta_{0}+\beta_{1} \mathrm{X}_{1}+\mathrm{e}$

Where $Y=$ Economic growth, $\beta_{0}=$ Regression intercept, $\beta_{1}=$ Regression coefficient, $X_{1}=$ Level of technology and e= term of error.

\section{Research Findings and Discussions}

The sample size of this study was population of 154 accredited fishers, 8 beach managers and 5 heads of state departments for trade directorates. From the accredited fishers, a response rate of $79.22 \%$ was obtained. In addition, 8 interviews were conducted and hence the response rate for the key informant interviews was $61.53 \%$. For the total sample size, a response rate of $77.84 \%$ was obtained. According to Fincham (2010), a response rate of 60 per cent is acceptable for analysis and a response rate of 75 per cent and above is excellent and can be used for analysis, for making conclusions and making inferences about a population.

\subsection{Economic Growth}

The measures of economic growth included more investments, high demand for labour, poverty reduction and increased foreign exchange. The respondents were requested to indicate their level of agreement on various statements relating to economic growth of small scale fish traders in Kisumu County. The respondents agreed with a mean of 4.02 and a standard deviation of 0.931 that Kenya-China trade relations have led to improved fish farming techniques locally. In addition, the respondents agreed with a mean of 3.84 and a standard deviation of 1.037 that Kenya-China trade relations have led to increased foreign exchange earnings. These findings agree with 
MOFCOM (2017) report that there were increased foreign exchange earnings from the bilateral relations between China and Kenya.

However, they were not sure with the statement indicating that Kenya-China trade relations have led to more investment in the fish industry as shown by a mean of 2.99 and a standard deviation of 1.074. These findings disagree with Khan and Baye (2008) findings that Cameroon-China trade ties dislodged probable and surviving local businesses resulting into stunted economic growth. Also, they were not sure with the statement indicating that Kenya-China trade relations have led to improved social welfare among fish traders as shown by a mean of 2.69 and a standard deviation of 1.034 .

The results show that the respondents disagreed with the statement indicating that Kenya-China trade relations have led to a high demand for labour in the fishery industry as shown by a mean of 1.66 and standard deviation of 0.758 . In addition, they disagreed with the statement indicating that Kenya-China trade relations have led to poverty reduction among fish traders as shown by a mean of 1.58 and a standard deviation of 0.889 . These findings agree with Wanjiku et al. (2018) argument that some Small and Medium scale businesses have been forced to close shop and a number of workers have been laid off due to the tough economic turbulence. According to the findings,the aggregate mean was 2.80 while the aggregate standard deviation was 0.954 .

Table 3: Economic Growth

\begin{tabular}{|c|c|c|}
\hline & SD D $\quad$ NSA SA Mear & $\begin{array}{l}\text { nStd. } \\
\text { Deviation }\end{array}$ \\
\hline Kenya-China trade relations have led to more investment in the fish industry. & 23.822.1.0 39.314 .82 .99 & 1.074 \\
\hline $\begin{array}{l}\text { Kenya-China trade relations have led to a high demand for labour in the fishery } \\
\text { industry. }\end{array}$ & y45.150.0.0 $4.1 \quad .8 \quad 1.66$ & .758 \\
\hline Kenya-China trade relations have led to poverty reduction among fish traders. & $\begin{array}{llll}58.234 .4 .0 & 5.7 & 1.6 & 1.58\end{array}$ & .889 \\
\hline Kenya-China trade relations have led to improved fish farming techniques locally. & $\begin{array}{lll}.8 & 12.3 .0 & 57.429 .54 .02\end{array}$ & .931 \\
\hline Kenya-China trade relations have led to improved social welfare among fish traders. & $15.644 .3 .8 \quad 34.44 .92 .69$ & 1.034 \\
\hline Kenya-China trade relations have led to increased foreign exchange earnings. & $\begin{array}{lllll}5.7 & 9.0 & 8 & 63.920 .53 .84\end{array}$ & 1.037 \\
\hline Aggregate & 2.80 & 0.954 \\
\hline
\end{tabular}

The accredited fishers were asked to list any other economic benefit from Kenya-China trade relations. From the results they indicated that other economic benefits include differentiated market products (variety to choose from), foreign exchange earnings through trade, improved infrastructure (transport and communication system), job opportunities for transporters, promotion of market access to Kenya's local products and entrepreneurship stimulation. These findings agree with Mugendi (2011) observation that Kenya-China bilateral relations transformed the transport sector. It led to the development of a sustainable urban transport system and also enhanced private sector participation in road infrastructural development leading up to economic growth and development.

\subsection{Chinese Level of Technology}

The study respondents (accredited fishers) were asked to indicate their extent of agreement with various statements on Chinese level of technology. From the findings, the respondents agreed with a mean of 3.76 and a standard deviation of 1.045 that Chinese level of technology has improved fish farming techniques at the local level. These findings are in line with Hongzou (2015) observation that free access to foreign technology strongly supported and enhanced the development of the fish industry. In addition, they agreed with a mean of 3.66 and a standard deviation of 1.161 that Chinese level of technology has boosted the number of locally equipped boats. These findings concur with FAO (2014) findings that scientific advancement and technological innovations form the basis of immense aquaculture production in China.

However, they disagreed with the statement indicating that Chinese level of technology has led to an increased volume and quality of fish production in local fish trade as shown by a mean of 1.51 and a standard deviation of 0.730. They also disagreed with the statement indicating that Chinese level of technology has facilitated low cost of fish production locally as shown by a mean of 1.47 and a standard deviation of 0.632 . 
Table 4: Chinese Level of Technology

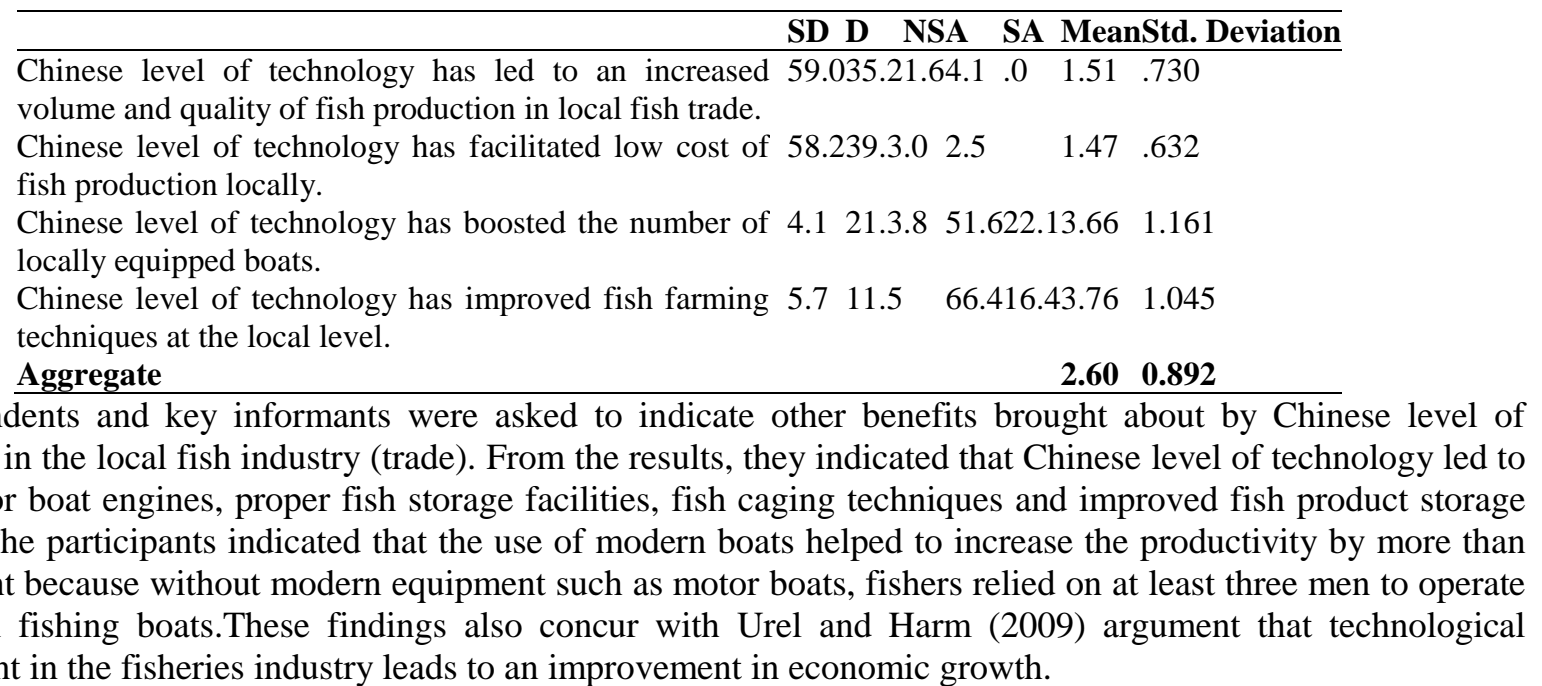

The respondents and key informants were asked to indicate other benefits brought about by Chinese level of technology in the local fish industry (trade). From the results, they indicated that Chinese level of technology led to cheap motor boat engines, proper fish storage facilities, fish caging techniques and improved fish product storage facilities. The participants indicated that the use of modern boats helped to increase the productivity by more than 100 per cent because without modern equipment such as motor boats, fishers relied on at least three men to operate the manual fishing boats.These findings also concur with Urel and Harm (2009) argument that technological development in the fisheries industry leads to an improvement in economic growth.

\subsection{Inferential Statistics}

This study used regression analysis to assess the effect of independent variable (Chinese level of technology) on the dependent variable (economic growth of small scale fish traders in Kisumu County).

The linear regression model was as follows:

$\mathrm{Y}=\beta_{0}+\beta_{1} \mathrm{X}_{1}+\mathrm{e}$

Where $Y=$ Economic growth, $\beta_{0}=$ Regression intercept, $\beta_{1}=$ Regression coefficient, $X_{1}=$ Level of technology and $e=$ term of error.

The r-squared for the relationship between Chinese level of technology effects and beaches and economic growth of small scale fish traders in Kisumu County was 0.709. This implies that the independent variable(s) (Chinese level of technology) could explain $26.5 \%$ of the dependent variable (economic growth of small scale fish traders in Kisumu County). This indicates that $73.5 \%$ of the economic growth of small scale fish traders in Kisumu County could be explained by other factors which were not put into consideration.

Table 5: Model Summary

\begin{tabular}{lllll}
\hline Model & R & R Square & Adjusted R Square & Std. Error of the Estimate \\
\hline 1 & $0.515^{\mathrm{a}}$ & 0.265 & 0.236 & 0.19463 \\
\hline
\end{tabular}

a. Predictors: (Constant), Chinese Level of Technology

As shown in Table 6, the association of the p value (0.000) less 0.05 shows significance. In addition, under the Fcalculated (619.262) was higher than F-critical (2.748). This implies that the model could be used in predicting the influence of independent variable (Chinese level of technology) on the dependent variable (economic growth of small scale fish traders in Kisumu County).

Table 6: Analysis of Variance

\begin{tabular}{llllll}
\hline & Sum of Squares & df & Mean Square & F & Sig. \\
\hline Regression & 23.459 & 1 & 23.459 & 619.262 & $.000^{\mathrm{b}}$ \\
Residual & 4.546 & 120 & .038 & & \\
Total & 28.005 & 121 & & & \\
\hline
\end{tabular}
a. Dependent Variable: Economic Growth
b. Predictors: (Constant), Chinese Level of Technology

The regression equation was;

$\mathrm{Y}=0.604+0.844 \mathrm{X}_{1}$

Furthermore, the results revealed that Chinese level of technology has a positive and significant effect on economic growth of small scale fish traders in Kisumu County $\left(\beta_{1}=0.844\right.$, p-value $\left.=0.021\right)$. The p-value $(0.000)$, which was less than 0.05 , shows significance. This implies that an improvement in Chinese level of technology leads to an improvement in economic growth of small scale fish traders in Kisumu County. The findings are in line with 
Hongzou (2015) findings that scientific advancement and technological innovations form the basis of immense aquaculture production in China.

Table 7: Regression Coefficients

\begin{tabular}{|c|c|c|c|c|c|}
\hline & \multicolumn{2}{|c|}{ Unstandardized Coefficients } & \multirow{2}{*}{$\begin{array}{l}\text { Standardized } \\
\text { Coefficients } \\
\text { Beta }\end{array}$} & \multirow[t]{2}{*}{$\mathbf{t}$} & \multirow[t]{2}{*}{ Sig. } \\
\hline & $\overline{\mathbf{B}}$ & Std. Error & & & \\
\hline (Constant) & .604 & .090 & & 6.716 & .000 \\
\hline Chinese Level of Technology & .844 & .034 & .915 & 24.885 & .000 \\
\hline
\end{tabular}

a. Dependent Variable: Economic Growth

\section{Summary, Conclusions and Recommendations}

\subsection{Summary of Findings}

The research was informed by the following objective; to determine the effect of Chinese level of technology on the economic growth of small scale fish traders in Kisumu County.

The research revealed that Chinese level of technology has a positive and significant association with economic growth of small scale fish traders in Kisumu County. The research also found that Chinese level of technology has improved fish farming techniques at the local level hence boosting the number of locally equipped boats.

\subsection{Conclusions}

The findings conclude that Chinese level of technology had a positive and significant effect on economic growth of small scale fish traders in Kisumu County. This shows that an improvement in Chinese level of technology would lead to an improvement in economic growth of small scale fish traders in Kisumu County. The findings show that Chinese level of technology leads to increased volume and quality of production, low cost of production, increased number of equipped boats and improved techniques of fish farming, which in turn improves economic growth of small scale fish traders in Kisumu County.

\subsection{Recommendations for Policy Implication}

The study highly recommends fishers to consider the full adoption of modern fish farming technology like fish caging and fish ranching as a way of improving fish volume hence improving their fish business.

The study also recommends accredited fishers in Kisumu County to utilize modern equipment and tools including the use of motor boats supplied by Chinese companies in their fishing business as well as cooling and storage facilities to facilitate large scale fish storage and longer preservation hours to boost business in Kisumu East SubCounty.

\subsection{Recommendation for Further Studies}

This study hence recommends for further studies on non-technological factors affecting the economic growth of small scale fish traders in Kisumu County.

\section{References}

Akoth, J.A. (2016). Influence of Climatic Elements and Non Climatic Factors on Fishing Activities in Lake Victoria.Kisumu County (Unpublished thesis).

Ames, B., Brown, W., Devarajan, S., Izquierdo, A. (2001).Macroeconomic Policy and Poverty Reduction. Washington, DC: International Monetary Fund.

Braunerhjem, P. (2009). Entrepreneurship, Innovation and Economic Growth-Past experience, current knowledge and policy implications. Working paper series in Economics and Institutions of Innovation 224. Royal Institute of Technology-Centre of Excellence for Science and Innovation Studies.

Chang, C., C. And Mendy, M. (2012). Economic Growth and Openness in Africa: What is the Empirical Relationship? Applied Economic Letters. 19(18), 1903-1907.

Chirwa, Themba\&Odhiambo, Nicholas. (2017). Sources of Economic Growth in Zambia: An Empirical Investigation. Global Business Review, 18, 9-21.

David, D.AndKraay, A. (2002). Growth is good for the Poor. Journal of Economic Growth, 7(3), 195-225.

FAO (2014). Fisheries and Aquaculture Country Profiles: The Peoples Republic of China. Fisheries and Aquaculture Department.Country brief.

Fields, S.G. (2006). A Public Lecture: Labour Markets and Economic Development. Journal of Eastern Caribbean Studies, 31(2), 72-84.

Fincham, E.J. (2010). Response Rate and Responsive Survey.Research Journal, 72(2), 23-38. 
GoK (2010).Implementation of Fishers Management Plan for Lake Victoria.EDF Project No. 8 ACP ROR 029.Unpublished Manual.Kisumu Department of Fisheries.

Haller, P., A. (2012). Concepts of Economic Growth and Development: Challenges of crisis and knowledge. Economy Transdisciplinarity cognition, 15(1), 66-77.

Hongzhou, Z. (2015). China's Fishing Industry and Current status, Government policies, and future prospects. $A$ paper for China as a 'Maritime Power'.July 28-29, 2015, Arlington, Virginia.

Husain, I. (2009). The Role of Politics in Pakistan Economy.Journal of International Affairs, 63, 1-18.

Ivic, M.M. (2015).Economic Growth and Development of Process Management.New Technologies International, $3(1), 55-56$.

Kamau, P. (2007). A Case Study-The Developmental Impact of Asian Drivers on Kenya with Emphasis on Textiles and Clothing Manufacturing. Mimeo.

Kamau, P. and Ngigi, S. (2013). Potential for women fish traders to upgrade within the fish trade value chain: Evidence from Kenya. DBA Africa Management Review, 3(2), 93-107.

Khan, A., S., and Baye, M., F. (2008). "China-Africa Economic Relations: The Case of Cameroon." Scoping Study for the AERC project:" The Impact of Asian Drivers on Sub-Saharan Africa. Ppno.Ssc-16 http://www.aercafrica.org/publication/category.asp.

KMFRI (2019).Kenya Aquaculture Brief 2019.State Department of Fisheries and Blue Economy Kenya.Kenya Marine and Fisheries Research Institute, Mombasa Kenya.

Kutner, M., Nachtsheim, J.C., and Neter, J. (2004).Applied Linear Regression Model.McGraw-Hill Irwin.

Lavvor, E. and Kapoguzov, E. (2006).Economic Growth: Theories and Problems, OmSu, Omsk.

MOFCOM (2017). China was a net exporter both in 2015 and 2016. Do it mean that China has entered a stage of net capital export? September 1, 2017. Jing ICP Bei No. 05004093.

Njoroge J. G. (2020) How Mobile Banking Technology Affects Kenyan Performance: A Case of Mobile Phone Companies in Kenya. The International Journal of Business \& Management ISSN 2321-8916 www.theijbm.com. Vol 8 Issue 5 May, 2020.

Nassiuma, D.K. (2000). Survey Sampling: Theory and Methods.Njoro, Kenya: Egerton University Press.

Nyandat, B. \&Owiti, G.O. (2013).Aquaculture Assessment Mission Report. Smart fish program of the Indian Ocean Commission, Ebene, Mauritus.

Omwenga, R.N., Abila, R., and Lwenya (2004).Fishing and Poverty levels along Lake Victoria (Kenya).Publication of Kenya Marine and Research Institute.

Onjala, J. (2008). A Scoping Study on China-Africa Economic Relations: The Case of Kenya. Institute of Development Studies.University of Nairobi.

Rao, B., B. And Hassan, G. (2011).A Pannel Data Analysis of Growth Effects of Remittances.Vol. 28. Economic Modelling. School of Economics and Finance.University of Western Sydney.

Siringi, E. (2018). Kenya China Trade Relations. A Nexus of "Trade not Aid" Investment opportunities for sustainable development. Journal of Economics and Finance, 6(12), 1-10.

Urel, B. and Harm, Z. (2009). The Dynamics of Provincial Growth in China: Nonparametric Approach. IMF Staff papers, 56(2), 239-262.

Wanjiku, S., Maingi, M., and Kamau, M. (2018)."Effects of Kenya's Bilateral Relations with China on Economic Growth of Kenya. (2000-2015) IOSR Journal of Economics and Finance (IOSR-JEF), 9(5), 13-21.

Wilson, J. (2014). Essentials of business research: A guide to doing your research project. Los Angeles, California: SAGE Publications. 